\title{
Meeting the meat: delineating the molecular machinery of muscle development
}

\author{
Arif Tasleem Jan ${ }^{\dagger}$, Eun Ju Lee ${ }^{\dagger}$, Sarafraz Ahmad and Inho Choi
}

\begin{abstract}
Muscle, studied mostly with respect to meat production, represents one of the largest protein reservoirs of the body. As gene expression profiling holds credibility to deal with the increasing demand of food from animal sources, excessive loss due to myopathies and other muscular dystrophies was found detrimental as it aggravates diseases that result in increased morbidity and mortality. Holding key point towards improving the developmental program of muscle in meat producing animals, elucidating the underlying mechanisms of the associated pathways in livestock animals is believed to open up new avenues towards enhancing the lean tissue deposition. To this end, identification of vital candidate genes having no known function in myogenesis, is believed to increase the current understanding of the physiological processes going on in the skeletal muscle tissue. Taking consequences of gene expression changes into account, knowledge of the pathways associated with their activation and as such up-regulation seems critical for the overall muscle homeostasis. Having important implications on livestock production, a thorough understanding of postnatal muscle development seems a timely step to fulfil the growing need of ever increasing populations of the world.
\end{abstract}

Keywords: Muscle, Muscle satellite cells, Muscle differentiation, Trans-differentiation

\section{Background}

Nutrition significantly influences the physical endurance and performance of living beings. For maximum performance, a diet that can provide a minimum half of our daily energy intake in the form of proteins and carbohydrates is recommended. Differences in food choice for optimal nutritional balance have led to selection of substrates of animal origin rich in proteins. To meet the modest increased interest in food from animal sources, most of the studies in livestock remain confined for being the main contributor of meat. Therefore, maintaining a balance between supply and demand requires a good understanding of muscle regulation to enable improved muscle mass without compromising animal health and meat quality. As contribution of livestock to mankind goes beyond food production to multipurpose uses, it became necessary to have a deep insight of the genetic machinery that regulates

\footnotetext{
*Correspondence: inhochoi@ynu.ac.kr

${ }^{\dagger}$ Equal contributors

School of Biotechnology, Yeungnam University, Gyeongsan 712-749, Republic of Korea
}

diverse cellular functions in consideration with their important economical role [1]. In this regard, studies pertaining to muscle development using a wide range of experimental models systems have opened up new avenues to gain better insight into changes in gene expression during different stages of growth and development.

Technological advancement that has led to methods such as microarrays, have shifted studies more toward global gene expression profiling $([2,3]$ and References therein). Rather than utilizing the $\mathrm{C} 2 \mathrm{C} 12$ cell line, primary cells compatible with in vivo environments were used to get accurate information regarding the roles of genes in muscle development [3]. Knowing the fact that factors responsible for muscle depot traits have pronounced effects on the taste and palatability of meat, a study was directed to investigate differences in the expression patterns of proteins among bovine primary muscle satellite cells (MSCs) from beef shank (BS), longissimus dorsi (LD), deep pectoral (DP) and semitendinosus (ST) muscle of Hanwoo cattle [2]. Microarray, expressed sequence tagging (EST) and RNA sequencing revealed 
information about importance of certain novel genes with unknown function, especially with regard to their differential expression in the myogenic program. Using primary cell culture system, gender-specific effect of serum components on the proliferation and differentiation of MSCs revealed male serum (MS) enhancing the proliferation and differentiation of MSCs, while female serum (FS) enhancing lipid accumulation associated with the taste and palatability of adipocyte-like cells (ALCs) [4-7]. Taken together, importance of differentially expressed genes such as fibromodulin (FMOD), matrix Gla protein (MGP), and transthyretin (TTR) with respect to regulation of the myogenic program was reported [2, 8-10]. Identification of differentially expressed genes eventually led to increased interest in studying their roles in the differentiation and transdifferentiation processes. Although studies establishing their roles in muscle development are still ongoing, studies are currently being pursued to delineate the accurate mechanism through which they act $[11,12]$. The present study was aimed to bring out state of art information regarding satellite cells and of the genes that play important role with respect to regulation of muscle cell program.

\section{Satellite cells in muscle development}

Muscle in all its forms makes up nearly half the body's mass. It is endowed with features of excitability (active response to stimulus), contractility (contraction upon stimulus), extensibility (stretchable capacity) and elasticity (ability to recoil and regain its normal length) that enable it to function [13]. In an intact muscle, the individual muscle fibres are wrapped and held together by connective tissue sheaths; namely, the epimysium, which is the outermost layer surrounding the entire muscle, the perimysium covering individual bundles or fascicles inside the perimysium, and the endomysium, which surrounds individual muscle fibres within fascicles. Together, these connective tissue sheaths support each cell and reinforce the muscle as a whole. Among the three muscle types, skeletal muscle represent highly adaptive tissue endowed with the ability to alter muscle mass and fiber size via the addition of new myonuclei in response to physiological stimuli. Being a form of striated muscle, it contributes to function and dysfunction of the musculoskeletal system. Although activated by reflexes, skeletal muscles composed of multinucleated myofibers are subjected to conscious (voluntary) control. Their fitness is correlated with two healthy states, strength and muscular endurance. Strength represents the force capacity and muscular endurance the ability to contract without getting exhausted.

Muscle cells, which are believed to be remnant embryonic myoblasts, comprise a population of muscle-specific progenitors that possess extraordinary regenerative capacity. Technological advancement has led to track their original location across a broad range of vertebrate species including mice [14-16], chicken [17, 18], rat [19] and humans $[20,21]$. Addition to generation of purified populations of MSCs using advanced techniques such as fluorescent-activated cell sorting (FACS), expression of $\beta$-galactosidase ( $\beta$-gal) or fluorophores (e.g., GFP) using nestin regulatory circuits has made their monitoring possible, even in freshly isolated myofibers $[22,23]$. Studies investigating the fusion of mononucleated myoblasts for generation of multi-nucleated myofibers set the stage for the current understanding of regeneration [24, 25]. Subsequent studies conducted by Konigsberg et al., [26] and Bischoff [27] provided substantial evidence of myofiber harbouring cells having the potential to give rise to myoblasts and multi-nucleated myotubes. Confirmation of sharing a similar anatomic position across the majority of vertebrates has led to acceptance of its candidature as source of myogenic cells necessary for postnatal growth.

Skeletal muscle originates from the mesodermal cells of somites and its development begins with the commitment of muscle satellite cells (MSCs) surrounding each myofiber to proliferate and differentiate to myoblasts. Despite the fact that myofiber number remains constant during early (neonatal/juvenile) stages of life, their contribution to growth is attributed to fusion of MSCs. MSCs represent $30 \%$ of the nuclei during early postnatal growth $[17,28]$. Being the main contributor to immediacy and sensitivity of skeletal muscle, MSCs play a key role in maintenance of the structural and functional integrity of muscle (Fig. 1). Subsequent to activation, about $80 \%$ (responsive population) of the MSCs enter the cell cycle phase, while the remaining $20 \%$ (reserve population) that represent the true stem cell population undergo symmetric divisions to replenish the quiescent cell pool $[29,30]$. Progression of MSCs along the myogenic lineage commences with the co-expression of paired box transcription factors, Pax3/Pax7, followed by contribution from basic helix loop helix (bHLP) family of transcription factors, commonly referred as myogenicregulatory factors (MRFs; including Mrf4, Myf5, MyoD and myogenin; MyoG) [31, 32]. The fate of MSCs is determined by changes in the pattern of expression of MRFs. For example, down regulation of Pax7 and upregulation of Myf5/MyoD followed by MyoG commits them to the myogenic program, while absence of MRFs leads to retention of the quiescence state among the satellite cell population [32, 33]. Regardless of origin, MSCs share Pax7 expression across all muscles $[34,35]$. Although exclusively expressed in the subpopulations of quiescent MSCs, the role of Pax3 is restricted to proliferation via induction of Myf5 because it does not play any indispensable role in quiescence. The stochastic down regulation of MyoD to retain the state of quiescence under in vitro 


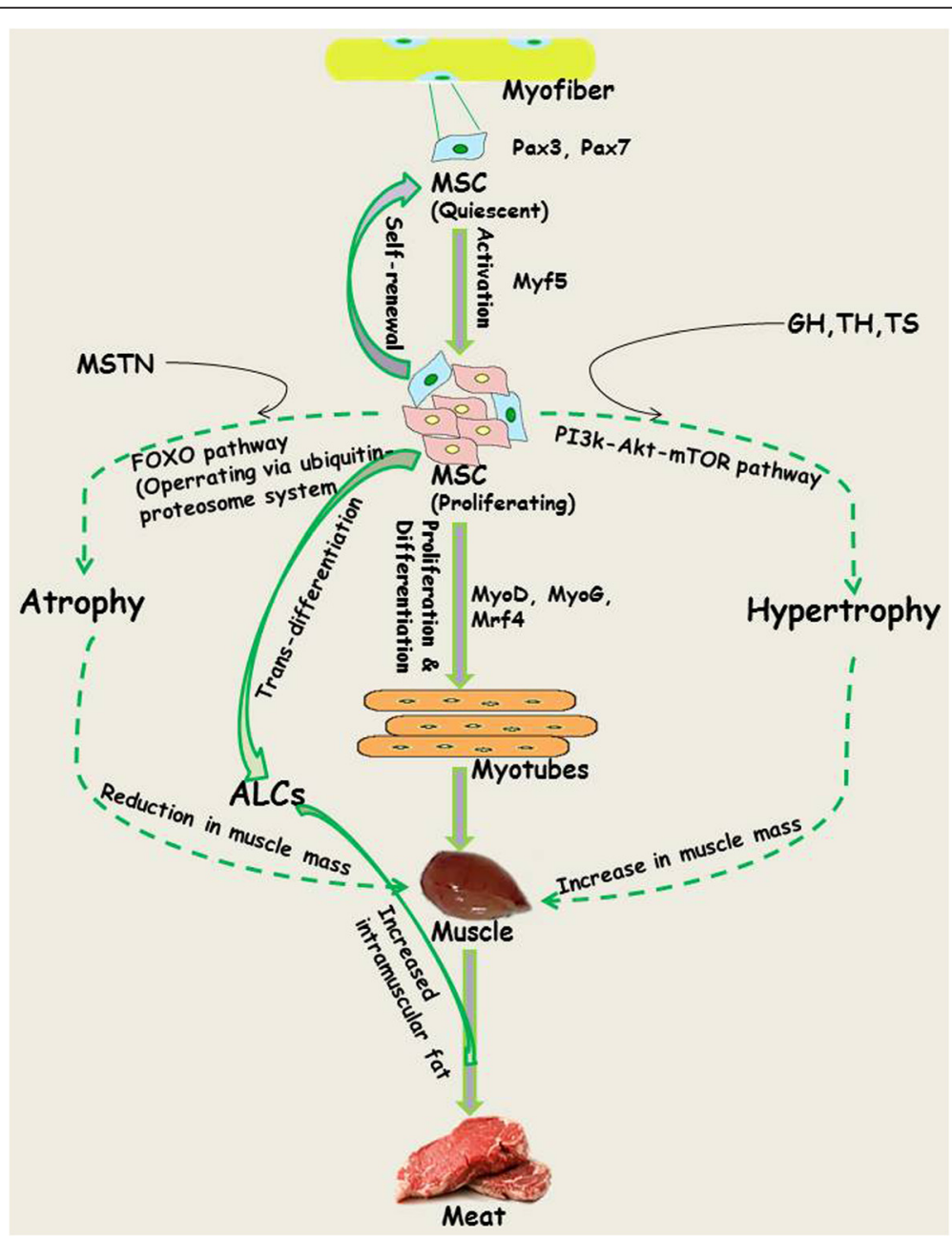

Fig. 1 A story of 3 M's (MSC's, Muscle and Meat). An outline depicting phases of transition of MSCs along with the role of transcriptional factors, genes and growth enhancing substances (hormones) associated the myogenic program

conditions is interpreted as the underlying mechanism for self-renewal of MSCs. Overall, it is the network of transcriptional factors that appears to control the progression of MSC lineage from origin towards myogenic specification, differentiation and then fusion to generate myoblasts.

\section{Myogenesis in livestock}

Subjected to intensive selection for improvement in terms of quality and quantity of meat, livestock breeds (cattle, sheep, poultry) represent useful genetic model for the study of hypertrophy and other muscle traits $[36,37]$. Although the extent of muscle cell multiplication determines how many muscle fibres are formed, the fate of growing muscle fibres during myogenesis depends largely on the extent of progenitor muscle cell multiplication. Being dependent on the number and proliferative stage of progenitor cells, maternal nutrition is known to have a dramatic effect on the development of skeletal muscle during this stage [38-41]. Prenatal myogenesis is divided into primary (embroyonic; during which primary muscle fibres arise) and secondary (fetal; leading to secondary muscle fibres) myogenesis. However, only a small fraction of primary muscle serves as template for secondary muscle fibres. Growth selection that led to increases in the proliferation rates of myoblast and/or satellite is represented by increased myonuclear numbers and higher muscle DNA content. Muscle fibres formed during the prenatal stage contributes significantly to growth and development of muscle in livestock. As such, genetic and environmental factors capable of influencing prenatal myogenesis act as a determining factor to the number of muscle fibres in any muscle. Muscle fibres number being essentially fixed at birth; therefore, postnatal growth results from the hypertrophy of existing muscle fibres in meat-producing animals [42, 43]. For contribution to hypertrophy of muscle fibres, nuclei being unable to divide are procured for incorporated into muscle fibres through 
the proliferative activity of MSCs. Hence, understanding the mechanism pertaining to prenatal development of skeletal muscle is important as it is well known for its dramatic impact on postnatal growth and development.

Increased muscle fibre number, which is attributed to the proliferative activity of MSCs during prenatal growth, markedly determines the growth and development capacity of postnatal muscles. However, increase in the mass during postnatal growth occurs due to increased muscle fibre size (length and girth) rather than muscle fibre number. Accordingly, MSCs remain the sole source that contributes for increase in the muscle fiber size. In addition to the increase in muscle fiber size, fusion of MSCs generates myoblasts with pre-existing muscle fibres that contribute to an increased number of nuclei in adult muscle fibres. Postnatal growth rate is inversely correlated with muscle fibre number, as muscle development was found lower due to high fibre numbers and higher owing to low number of fibres. It has been suggested that this occurs owing to reduced energy and oxygen supply by lower capillary density, as well as impairment of the nuclear control of cellular processes due to low nuclear: cytoplasm ratio [44-46]. In short, there is clear antagonism between muscle fibre number and thickness, with low fibre number correlating with fibres that exhibit higher hypertrophy. It has been reported that muscle hypertrophy that lead to increase in muscle mass reduces the stress adaptability of fibres, which in turn is associated with poor meat quality of major livestock breeds [46-49]. Hence, having a better knowledge of the involvement of MSCs in postnatal hypertrophy is essential to improve the efficiency of muscle growth in meat-producing animals.

\section{Muscle homeostasis: balance of atrophy and hypertrophy}

Muscles are highly adaptable owing to their remarkable plasticity. They arise as multinucleate syncytium from the fusion of mononuclear myoblasts. An intricate balance between production and degradation of myofibrils is crucial to muscle growth and maintenance of healthy state [50, 51]. In addition to mammals, studies of Drosophila highlighted the role pertaining to balance in the protein content (synthesis and breakdown) in determining the fate of muscle tissue [51]. By regulating the number of cells capable of undergoing proliferation, MSCs modulate myofiber growth accordingly. To ensure constant and harmonious growth of all muscles, cellular turnover (addition of new myonuclei via fusion of satellite cells) in addition to maintenance of proteins appears crucial during early embryonic development in the muscle development program. Contribution of cellular turnover to the homeostasis of adult fibres is achieved through increased synthesis rather than degradation of proteins. Adhering to this, the interrelated processes are tightly regulated 1 ) at the level of protein synthesis through degradation of the misfolded proteins, and 2) at the level of protein degradative machinery required to replace proteins as a result of changes in muscle activity. The net difference in these two processes contributes to gross protein deposition, which is manifested as muscle hypertrophy.

Coordinated regulation in the pathways controlling synthesis and degradation of muscle proteins strongly influences the physical endurance of the growing muscle [52]. In efforts to elucidate the pathways controlling cellular and protein turnover, application of genetic approaches for gain or loss of function mutation has helped in establishing their role in muscle hypertrophy or reduced muscle growth [51]. Muscle specific over-expression of insulin like growth factor 1 (IGF-1) or Akt by employing a transgenic module through electroporation leads to restoration of muscle growth with matching physiological strength and displays higher regeneration potential for sustainable muscle growth [53, 54]. IGF-1 is known to activate mitogen-activated protein kinase/extracellular signal reduced kinase (MEPK/ERK) and phosphoinositide 3-kinase (PI3)-Akt pathways, which are in turn associated with the induction of muscle growth either by stimulating protein synthesis through mammalian target of Rapamycin (mTOR) or by inhibiting the degradative machinery induced by forkhead box O (FOXO) transcription factors. Upon activation by Akt, mTOR act through two different branches of the Akt pathway; Rapamycin-sensitive TORC1 containing raptor and Rapamycin-insensitive TORC2 containing rictor ([55] and references therein). Conversely, reduced PI3k signalling causes decreased protein synthesis machinery and a subsequent increase in proteolysis through FOXO mediated expression of the atrogene program. In addition to reduced PI3k signalling during fasting and in diseased state, increased expression of myostatin (MSTN) leads to inhibition of PI3k-Akt signalling [54]. Overall, this pathway has a positive effect on regulation of muscle growth by stimulating protein synthesis and inhibiting the degradation trigger of proteins by the FOXO system via the ubiquitin-proteosome system (UPS) and autophagy (Fig. 1).

MSTN (also referred as growth and differentiation factor-8, GDF-8), a member of the transforming growth factor- $\beta$ (TGF- $\beta$ ) family expressed and secreted by skeletal muscle tissues, is an endogenous negative regulatory factor that regulates growth and development of the muscle [56-58]. Its function as a negative regulator was first reported by McPherron et al., [59] through studies on MSTN null $\left(\mathrm{MSTN}^{-/}\right)$mice, exhibiting double mass attributed by combination of increased number (hyperplasia) and size (hypertrophy) of muscle fibres. This effect was observed through regulation of muscle fiber sizes rather than contribution from MSCs, which are devoid of MSTN receptors [60-62]. MSTN, which is expressed 
primarily by myotubes, acts as an inactive precursor protein in the extracellular matrix of muscle and/or remains in circulation as an endocrine hormone until it undergoes proteolytic cleavage followed by dimerization of the $C$-terminal to generate active MSTN [63, 64]. However, until its release from the cell it remains inactive through the formation of a latent complex with the $\mathrm{N}$-terminal propeptide [65-67].

Subsequent to activation (removal of $\mathrm{N}$-terminal propeptide), mature myostatin binds to its transmembrane receptor, activin receptor protein type IIB/A (ActRIIB/ A), which undergoes dimerization with activin type I receptors (ALK-4/5) to induce signalling in the internal cellular environment through Smad proteins [68-70]. Activation of Smad2 and Smad3 lead to heterodimer complex formation with the common mediator, Smad4. Subsequent to translocation to the nucleus, Smad complex (Smad2,-3,-4) activates transcription of target genes though interaction with the DNA $[71,72]$ or block the fusion of proliferating myoblasts after transactivation of MyoD [73, 74]. Additionally, Smad complex activates signalling along the Erk1/2 MAPK pathway to prevent myoblasts proliferation via $\mathrm{p} 21 / \mathrm{Rb}$ signalling cascade and promotion of anti-apoptotic pathways via activation of p53 in differentiated cells. Upon activation, Smad7 (inhibitory Smad protein) functions as a negative feedback inhibitor for the MSTN signalling pathway $[58,75,76]$.

Corresponding to muscle progenitor cells, MSTN maintains a fine balance between proliferation and differentiation; however, any disturbance to this balance changes this to either differentiation (in the case of over-expression) or proliferation (inhibition of MSTN), which leads to expansion of progenitor cell pool. Furthermore, reports have suggested that inhibition of the PI3K/Akt/mTOR signalling pathway occurs via phosphorylated SMAD3 through induction of the E3-ligase, atrogin-1 [77, 78]. Another study reported that induction of the degradation of muscle protein through ubiquitin-proteasome machinery inhibit the PI3K/Akt/mTOR signalling pathway [79]. Taken together, these studies suggest the possibility of cross-talk at different levels between MSTN and PI3K/Akt/mTOR signalling pathways.

\section{Hormonal regulation of muscle mass}

Regulation of growth occurs through the substantial involvement of neuro-endocrine system as well as local autocrine/paracrine actions of hormones and growth factors. These compounds elicit their effects either through changes in their local production or with respect to their activity in controlling the myogenic stages of muscle cells. A key prerequisite for optimised muscle growth involves the balanced secretion of two hormones, growth hormone $(\mathrm{GH})$ and testosterone (T). Growth hormone $(\mathrm{GH})$ stimulates growth, cell reproduction and regeneration in humans and other animals. Used mainly as a performance enhancing drug, $\mathrm{GH}$ stimulates production of IGF-1, a peptide hormone homologous to proinsulin from the liver through JAK-STAT pathway ([80] and references therein). Acting via IGF-1, GH produces its effect through the stimulation of MSC proliferation along with synthesis of proteins in muscle. The growth stimulating effects of IGF-1 have been reported from a wide variety of tissues. Postnatal application of $\mathrm{GH}$ leads to an increase in lean growth and decrease in fat deposition, and often stimulates muscle fibre hypertrophy [81, 82].

To accomplish this, the most frequent mechanism of change in thyroid hormone (TH) level is GH-mediated increase in $\mathrm{T}_{4}$ to $\mathrm{T}_{3}$ conversion by means of deiodination in target tissues $[10,83]$. Binding of THs to their distributor proteins (thyroxine-binding globulin (TBG), transthyretin (TTR) and albumin) facilitates their distribution to a greater extent. TBG exhibiting highest affinity $\left(1.0 \times 10^{10} \mathrm{M}^{-1}\right.$ and $\left.4.6 \times 10^{8} \mathrm{M}^{-1}\right)$ leads the group for transporting T4 and T3, followed by TTR $\left(7.0 \times 10^{7} \mathrm{M}^{-1}\right.$ and $\left.1.4 \times 10^{7} \mathrm{M}^{-1}\right)$ and then albumin $\left(7.0 \times 10^{5} \mathrm{M}^{-1}\right.$ and $1.0 \times 10^{5} \mathrm{M}^{-1}$ ) [84]. Taken together, all three proteins constitute a buffering network for T4 in the blood, which provides a means of protection against fluctuation in the level of THs that can led either to hypothyroidism or hyperthyroidism. Regardless of variation in the concentration of distributing proteins, TBG $(0.015 \mathrm{~g} / \mathrm{l})$ is known to distribute major proportion (up to $75 \%$ ) of T4 and T3 followed by $\operatorname{TTR}(0.25 \mathrm{~g} / \mathrm{l})$ and albumin $(42 \mathrm{~g} / \mathrm{l})$, which distribute $15 \%$ and $10 \%$, respectively (Alshehri et al. [84]). Concentration of $\mathrm{TH}$ distributor proteins having high binding affinity for THs prevents partitioning of THs into the lipid component of the cell membrane, thereby ensures a continuous pool of circulating $\mathrm{THs}$ in the blood [85, 86].

Although synthesis of TTR is restricted to the liver, its synthesis has also been reported in the choroid plexus of brain and in muscle tissues [2, 9, 87, 88]. Besides transporting thyroxine, TTR is known to assist in the transport of retinol through its binding to retinol-binding protein (RBP) [89]. Having dual role in transport thyroxine and retinol fetches it with the name TransThyRetin. In mammals, TTR possesses higher binding affinity for T4 than its active form, T3, while all other vertebrate species exhibit higher binding affinity of TTR for T3 than T4. Transit times for delivery of THs to tissues vary according to the binding affinities of different $\mathrm{TH}$ distributor proteins. As such TTR having intermediate affinity is responsible for immediate delivery of THs to tissues compared to TBG, which holds THs tightly and albumin, which binds THs loosely to deliver them at their specific sites $[9,84]$. At the tissue level, particularly in muscle, TTR was found to play a critical role in transporting and delivering $\mathrm{T} 4$ to cells. 
Using knockdown approach, we demonstrated that TTR was more involved in differentiation than proliferation. During differentiation, TTR was found to be associated with regulation of the expression of early stage genes such as myosin light chain 2 (MYL2), as well as in affecting the functioning of $\mathrm{Ca}^{2+}$ channel genes such as Cav1.1 and Cav3.1 $[8,10]$.

TTR is highly conserved in terms of structure across a broad range of species. Once reaching the respective destination, it is acted upon by a family of deiodinases that either activates it via T4 to $\mathrm{T} 3$ conversion or inactivates it following conversion to either T2 or rT3 [90]. Following binding to thyroid receptors (TRs), T3 undergoes translocation to the nucleus, where it acts on the promoter region of certain specific genes, thereby causing dissociation of corepressor molecules or association of coactivator proteins. Secretion of T4 from thyroid gland contributes to first level T3 availability to cells. The second level of regulation occurs at the peripheral level, where TH transporters (MCT8, MCT10 and OATP1C1) and TH metabolising enzymes (deiodinases) regulate intracellular T3 levels in a tissue-specific fashion.

The growth promoting effects of steroids (anabolic hormones) are well known in cattle, whereas limited effects are known from swine [91]. Indeed, steroids have long been used to improve the efficiency and product quality of animal meat. Testosterone (TS) is known for its ability to control the number and size of muscle fibre. TS has also been found to stimulate growth of existing myofibres longitudinally to increase number of fibre per cross sectional area of muscle. Postnatal application of testosterone stimulates muscle fibre hypertrophy directly or indirectly without increasing fibre number through stimulation in the satellite cell proliferation and synthesis of muscle proteins [4, 92-94]. However, in the case of males and females, difference in fibre number arises via hormonal action during prenatal period of fibre formation. While the male sex hormone plays an important role in enhancing proliferation and differentiation of MSC, the female sex hormone is influential in the transition of MSCs towards transdifferentiation, which causes lipid accumulation in differentiating myotubes [94, 95]. Increased intramuscular fat is desirable in the meat industry as it marginally increases tenderness, juiciness and flavor intensity. Based on this knowledge, growthpromoting agents that can influence muscle growth in farm animals have been derived. There have also been reports of growth-promoting effects exerted by $\beta$ adrenergic agonists among various species [96-99]. In contrast to $\mathrm{GH}$, most $\beta$-adrenergic agonists are not able to stimulate MSC proliferation, and instead produce short term effects by increasing protein synthesis in the muscle fibres.

\section{Meat quality: a parameter needed for consumer satisfaction}

Optimal meat quality represents a complex of intrinsic (e.g. color stability, tenderness, palatability and waterholding capacity) and extrinsic (e.g. price, brand name, origin, packaging, labelling, etc) characteristics, that are meant to satisfy consumers. Optimal meat quality characteristics vary with human culture and time, with a general trend of increasing contribution to safety and healthiness that are important for consumption and economic reasons. With increasing demand for products with enhanced safety and healthiness, food production systems with improved quality standards are important to deliver and guarantee the safety of the products to consumers. Variation in meat quality arises through differences in the metabolic processes occurring in the muscles during peri- and post-slaughter period. Accordingly, muscle fibre type and capillarity within animals are important factors $[46,100]$. Meat quality is generally accessed in terms of tenderness, taste, etc. Tenderness of meat is positively related to the muscle fibre characteristics (cross-sectional areas of the fibres, fibre types, metabolic enzyme activities, collagen quantity) and the amount of intramuscular fat that contribute to determination of flavor $[101,102]$. Color of meat is determined by the level of myoglobin oxygenation [100]. Meat with high percentages of oxidative fibres (greater myoglobin content) has a red color. These fibres show a high level of post-mortem shortening and generally have a low glycogen content. Capillarization is another relevant factor that influences meat quality since it is associated with supply of oxygen to muscles fibres. Through this, capillarization not only influences the metabolic state at time of slaughter but also during post-slaughter period.

Adipogenesis overlaps myogenesis during mid-gestation period in ruminant animals and humans [103-105]. Commitment of MSCs to adipogenic lineages (transdifferentiation) being in competition with the regular myogenic (differentiation) program, is shaped through the involvement of numerous inductive regulators (Fig. 2). Progressive loss of muscle mass that exerts negative effect on the structural and functional integrity of muscle fibre results in the decline of muscle strength [106, 107]. However, switching the commitment of MSCs from myogenic to adipogenic program during fetal muscle development results in increased intramuscular fat and therefore marbling in the offspring $[40,108-110]$. Being crucial to the flavor of meat, enhancement of intramuscular fat through increased number and size of intramuscular adipocytes improves meat quality [103, 111, 112]. Growing demand for highly marbled meat has resulted in exploration of the inducers that can cause transition of MSCs towards adipose-like cells (ALCs) within muscle [3, 113, 114]. In search for inducers, role of adipogenic transcriptional 


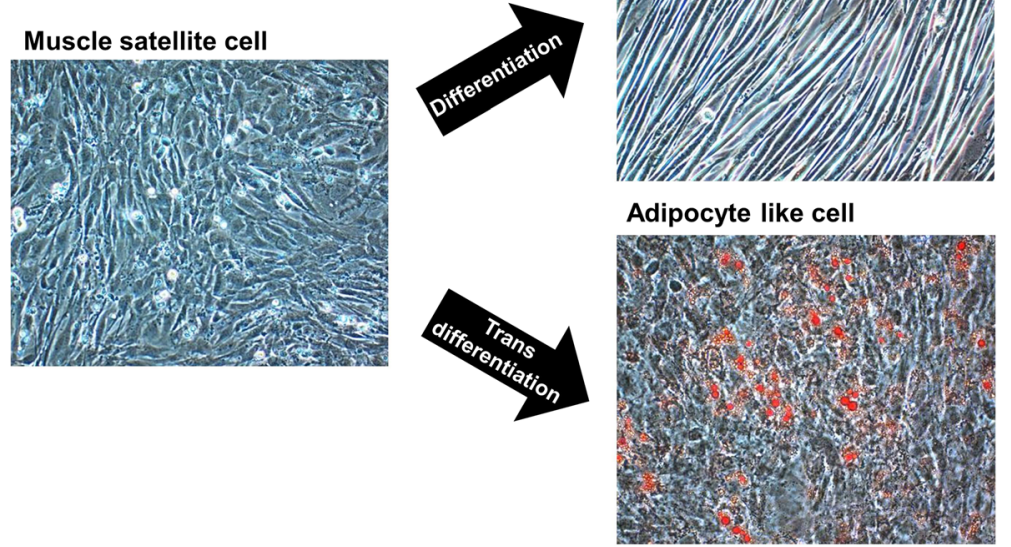

Fig. 2 Switching of primary bovine MSC's to myogenic (differentiation) or adipogenic (trans-differentiation) program. Left panel represent proliferating MSCs while as panel on the right indicate cells under differentiating and trans-differentiating conditions

factors CCAAT-enhancer binding protein alpha $(C / E B P \alpha)$ and peroxisome proliferator-activated receptor gamma (PPAR $\gamma$ ) was found conserved [5, 115-117]. Considering the importance of fat in muscle to meat industry, ligands such as thiazolidinediones, which activates the function of transcription factors $\mathrm{C} / \mathrm{EPB} \alpha$ and PPAR $\gamma$, are being used to induce transdifferentiation in MSCs [117-119]. While maternal over-nutrition has been found to increase adipocytes during late gestation in the skeletal muscles of fetal sheep [41, 120], controlled concentrations of serum lipids have been shown to induce transdifferentiation of MSCs into adipoblasts $[5,119]$.

\section{Conclusion}

Growth rate corresponding to muscle is considered an important performance factors for evaluating profits. Studies of MSC populations have enhanced the current understanding of the regulatory mechanisms that direct somatic stem cell populations for their role in the developmental program. Advancement in the high-throughput sequencing and system biology that advanced the search for such genes have made it possible to elucidate a core regulatory network of myogenic genes that drives the myogenic fate of pluripotent stem cells. This program, though orchestrated by key transcription factors, dictates the balance between proliferation and differentiation and drives the functional transformation from individual proliferating myogenic cells to a syncytial contractile myofiber. Additionally, increasing knowledge obtained through in silico studies of differentially expressed genes has provided an outstanding tool for investigating the interacting network operating between different genes to elucidate the molecular machinery behind activation, proliferation and differentiation of MSCs. To meet the growing demand of the increasing population, exploiting the regulatory circuits through the use of primary culture system is believed to provide deep insight into the measures that can be employed for improving the postnatal skeletal muscle growth among different animal species. As such, understanding genetic and epigenetic regulation of cell pluripotency, reprogramming and cell differentiation/ dedifferentiation seems critical to improve livestock production.

Competing interests

The authors declare that they have no competing interests.

\section{Authors' contributions}

IC and ATJ conceived the idea and coordinated in designing and drafting the manuscript. ATJ and EJL contributed equally to writing. SA helped in proof reading and for positive criticism that helped in upgrading the quality of manuscript. All authors read and approved the final manuscript.

\section{Acknowledgement}

This work was supported by a National Research Foundation of Korea (NRF) grant funded by the Republic of Korea government (MSIP; no. 2014R1A2A2A01006324) along with the Basic Science Research Program through the National Research Foundation of Korea (NRF) funded by the Ministry of Education (NRF-2013R1A1A2059308).

Received: 15 February 2016 Accepted: 7 April 2016

Published online: 10 May 2016

\section{References}

1. Bettencourt EMV, Tilman M, Narciso V, Carvalho MLS, Henriques PDS. The livestock roles in the wellbeing of rural communities of Timor-Leste. Rev de Eco Soc Rural. 2015;53(S1):63-80.

2. Lee EJ, Lee HJ, Kamli MR, Pokharel S, Bhat AR, Lee YH, Choi BH, Chun TH, Kang SW, Lee YS, Kim JW, Schnabel RD, Taylor JF, Choi I. Depot-specific gene expression profiles during differentiation and transdifferentiation of bovine muscle satellite cells, and differentiation of preadipocyte. Genomics. 2012a;100:195-202. 
3. Lee EJ, Bajracharya P, Lee DM, Kang SW, Lee YS, Lee HJ, Hong SK, Chang JS, Kim JW, Schnabel RD, Tayler JF, Choi I. Gene expression profiles during differentiation and transdifferentiation of bovine myogenic satellite cells. Genes Genom. 2012b;34:133-48.

4. Lee EJ, Bajracharya P, Jang EJ, Lee HJ, Jang JS, Hong SG, Choi I. Effect of sex steroid hormones on bovine myogenic satellite cell proliferation, differentiation and lipid accumulation in myotube. Asian-Austra J Ani Sci. 2010;23:649-58.

5. Lee SJ, Lee EJ, Kim SH, Choi I, Lee DM, Lee HJ, Yoon DH, Chun TH. IL-17A promotes transdifferentiation of myoblasts into adipocytes by increasing expression of PPARy through C/EBPß. Biotech Lett. 2011;33:229-35.

6. Kim JH, Kim M, Nahm SS, Lee DM, Pokharel S, Choi I. Characterization of Gender-Specific Bovine Serum. Anim Cell Sys. 2011;15:147-54.

7. Park JH, Park JH, Nahm SS, Choi I, Kim JH. Identification of anti-adipogenic proteins in adult bovine serum suppressing the differentiation of 3T3-L1 preadipocytes. BMB Rep. 2013;46:582-7.

8. Lee EJ, Kamli MR, Pokharel S, Malik A, Tareq KMA, Bhat AR, Park HB, Lee YS, Kim SH, Yang BS, Jeong KY, Choi I. Expressed sequence tags for bovine muscle satellite cells, myotube-formed cells and adipocyte-like cells. PLOS ONE. 2013a;8(11):e79780.

9. Lee EJ, Bhat AR, Kamli MR, Pokharel S, Chun T, Lee YH, Nahm SS, Nam JH, Hong SK, Yanh B, Chung KY, Kim SH, Choi I. Transthyretin is a key regulator of myoblast differentiation. PLoS ONE. 2013b;8(5):e63627.

10. Pokharel S, Kamli MR, Mir BA, Malik A, Lee EJ, Choi I. Expression of transthyretin during bovine myogenic satellite cell differentiation. In Vitro Cel Dev Biol-Anim. 2014;50:756-65.

11. Lee EJ, Malik A, Pokharel S, Ahmad S, Mir BA, Cho KH, Kim JH, Kong JC, Lee DM, Chung KY, Kim SH, Choi I. Identification of genes differentially expressed in myogenin knock-down bovine muscle satellite cells during differentiation through RNA sequencing analysis. PLoS ONE. 2014a;9:e92447.

12. Malik A, Lee EJ, Jan AT, Ahmad S, Cho KH, Kim J, Choi I. Network analysis for the identification of differentially expressed hub genes using myogenin knock-down muscle satellite cells. PLoS ONE. 2015;10(7):e0133597.

13. Yin H, Price F, Rudnicki MA. Satellite Cells and the Muscle Stem Cell Niche Physiol Rev. 2013;93(1):23-67.

14. Zammit PS, Golding JP, Nagata Y, Hudon V, Partridge TA, Beauchamp JR. Muscle satellite cells adopt divergent fates: a mechanism for self-renewal? J Cell Biol. 2004;166:347-57.

15. Day K, Shefer G, Richardson JB, Enikolopov G, Yablonka-Reuveni Z. NestinGFP reporter expression defines the quiescent state of skeletal muscle satellite cells. Dev Biol. 2007;304:246-59.

16. Day K, Shefer G, Shearer A, Yablonka-Reuveni Z. The depletion of skeletal muscle satellite cells with age is concomitant with reduced capacity of single progenitors to produce reserve progeny. Dev Biol. 2010;340:330-43.

17. Halevy O, Piestun $Y$, Allouh MZ, Rosser BW, Rinkevich $Y$, Reshef $R$, Rozenboim I, Wleklinski-Lee M, Yablonka-Reuveni Z. Pattern of Pax7 expression during myogenesis in the posthatch chicken establishes a model for satellite cell differentiation and renewal. Dev Dyn. 2004;231:489-502.

18. Allouh MZ, Yablonka-Reuveni Z, Rosser BW. Pax7 reveals a greater frequency and concentration of satellite cells at the ends of growing skeletal muscle fibers. J Histo Cytochem. 2008;56:77-87.

19. Shefer G, Rauner G, Yablonka-Reuveni Z, Benayahu D. Reduced satellite cell numbers and myogenic capacity in aging can be alleviated by endurance exercise. PLoS ONE. 2010:5:e13307.

20. Lindstrom M, Thornell LE. New multiple labelling method for improved satellite cell identification in human muscle: application to a cohort of power-lifters and sedentary men. Histochem Cell Biol. 2009;132:141-57.

21. Lindstrom M, Pedrosa-Domellof F, Thornell LE. Satellite cell heterogeneity with respect to expression of MyoD, myogenin, Dlk1 and c-Met in human skeletal muscle: application to a cohort of power lifters and sedentary men. Histochem Cell Biol. 2010;134:371-85.

22. Beauchamp JR, Heslop L, Yu DS, Tajbakhsh S, Kelly RG, Wernig A, Buckingham M, Partridge TA, Zammit PS. Expression of CD34 and Myf5 defines the majority of quiescent adult skeletal muscle satellite cells. J Cell Biol. 2000;151:1221-34.

23. Montarras D, Morgan J, Collins C, Relaix F, Zaffran S, Cumano A, Partridge T, Buckingham M. Direct isolation of satellite cells for skeletal muscle regeneration. Science. 2005;309:2064-7.

24. Capers CR. Multinucleation of skeletal muscle in vitro. J Biophy Biochem Cytol. 1960;7:559-67.
25. Cooper WG, Konigsberg IR. Dynamics of myogenesis in vitro. Anat Rec. 1961;140:195-205.

26. Konigsberg UR, Lipton BH, Konigsberg IR. The regenerative response of single mature muscle fibers isolated in vitro. Dev Biol. 1975;45:260-75.

27. Bischoff R. Regeneration of single skeletal muscle fibers in vitro. Anat Rec. 1975:182:215-35.

28. Hawke TJ, Garry DJ. Myogenic satellite cells: physiology to molecular biology. J Appl Physiol. 2001;91:534-51.

29. Collins CA, Olsen I, Zammit PS, Heslop L, Petrie A, Partridge TA, Morgan JE. Stem cell function, self-renewal, and behavioral heterogeneity of cells from the adult muscle satellite cell niche. Cell. 2005;122:289-301.

30. Sacco A, Doyonnas R, Kraft P, Vitorovic S, Blau HM. Self-renewal and expansion of single transplanted muscle stem cells. Nature. 2008;456:502-6.

31. Zammit P, Beauchamp J. The skeletal muscle satellite cell: stem cell or son of stem cell? Differentiation. 2001;68:193-204.

32. Day K, Paterson B, Yablonka-Reuveni Z. A distinct profile of myogenic regulatory factor detection within $\mathrm{Pax} 7^{+}$cells at $\mathrm{S}$ phase supports a unique role of Myf5 during post hatch chicken myogenesis. Dev Dyn. 2009;238:1001-9.

33. Buckingham M, Relaix F. The role of Pax genes in the development of tissues and organs: Pax3 and Pax7 regulate muscle progenitor cell functions. Ann Rev Cell Dev Biol. 2007;23:645-73.

34. Harel I, Nathan E, Tirosh-Finkel L, Zigdon H, Guimaraes-Camboa N, Evans SM, Tzahor E. Distinct origins and genetic programs of head muscle satellite cells. Dev Cell. 2009;16:822-32.

35. Ono Y, Boldrin L, Knopp P, Morgan JE, Zammit PS. Muscle satellite cells are a functionally heterogeneous population in both somite-derived and branchiomeric muscles. Dev Biol. 2010;337:29-41.

36. Lehnert SA, Reverter A, Byrne KA, Wang Y, Nattrass GS, Hudson NJ, Greenwood PL. Gene expression studies of developing bovine longissimus muscle from two different beef cattle breeds. BMC Dev Biol. 2007;7:95.

37. Lee SH, Park BH, Sharma A, Dang CG, Lee SS, Choi TJ, Choy YH, Kim HC, Jeon KJ, Kim SD, Yeon SH, Park SB, Kang HS. Hanwoo cattle: origin, domestication, breeding strategies and genomic selection. J Anim Sci Tech. 2014b;56:2.

38. Zhu MJ, Ford SP, Nathanielsz PW, Du M. Effect of maternal nutrient restriction in sheep on the development of fetal skeletal muscle. Biol Rep. 2004b;71:1968-73.

39. Zhu MJ, Han B, Tong J, Ma C, Kimzey JM, Underwood KR, Xiao Y, Hess B W, Ford SP, Nathanielsz PW, Du M. AMP-activated protein kinase signalling pathways are down regulated and skeletal muscle development impaired in foetuses of obese, over-nourished sheep. J Physiol. 2008;586:2651-64.

40. Tong JF, Yan X, Zhu MJ, Ford SP, Nathanielsz PW, Du M. Maternal obesity downregulates myogenesis and beta-catenin signaling in fetal skeletal muscle. Am J Physiol End Met. 2009;296:E917-924.

41. Yan X, Zhu MJ, Xu W, Tong JF, Ford SP, Nathanielsz PW, Du M. Up-regulation of Toll-like receptor 4/nuclear factor-kappaB signaling is associated with enhanced adipogenesis and insulin resistance in fetal skeletal muscle of obese sheep at late gestation. Endocrinol. 2010;151:380-7

42. Morgan JE, Partridge TA. Muscle satellite cells. Int J Biochem Cell Biol. 2003; 35:1151-6.

43. Kamanga-Sollo E, White ME, Chung KY, Johnson BJ, Dayton WR. Potential role of G-protein-coupled receptor 30 (GPR30) in estradiol-17betastimulated IGF-I mRNA expression in bovine satellite cell cultures. Domes Ani End. 2008:35:254-62.

44. Cheek DB, Hill DB, Cornando A, Graham GG. Malnutrition in infancy: changes in muscle and adipose tissue before and after rehabilitation. Paediat Res. 1970;4:135-44.

45. Cassens RG, Cooper CC. Red and white muscle. Adv Food Res. 1971;19:1-74.

46. Henckel P, Oksbjerg N, Erlandsen E, Barton-Gade P, Bejerholm C. Histo- and biochemical characteristics of the longissimus dorsi muscle in pigs and their relationships to performance and meat quality. Meat Sci. 1997;47:311-21.

47. Fiedler I, Ender K, Wicke M, Maak S, Von Lengerken G, Meyer W. Structural characteristics of muscle fibres in pigs with different malignant hyperthermia susceptibility and different meat quality. Meat Sci. 1999:53:9-15.

48. Bhasin S, Woodhouse L, Storer TW. Proof of the effect of testosterone on skeletal muscle. J Endocri. 2001:170:27-38.

49. Halevy O, Krispin A, Leshem Y, McMurtry JP, Yahav S. Early age heat exposure effects skeletal muscle satellite cell proliferation and differentiation in chicks. Am J Physiol Reg Integ Comp Physiol. 2001;281:302-9. 
50. Sartorelli V, Fulco M. Molecular and cellular determinants of skeletal muscle atrophy and hypertrophy. Sci STKE. 2004;244:re11.

51. Sandri M. Signalling in muscle atrophy and hypertrophy. Physiology. 2008;23:160-70

52. Egerman MA, Glass DJ. Signalling pathways controlling skeletal muscle mass. Crit Rev Biochem Mol Biol. 2014:49:59-68.

53. Bonaldo P, Sandri M. Cellular and molecular mechanisms of muscle atrophy. Dis Mod Mech. 2013;6:25-39.

54. Cohen S, Nathan JA, Goldberg AL. Muscle wasting in disease: molecular mechanism and promising therapies. Nat Rev Drug Dis. 2015;14:58-74.

55. Laplante M, Sabatini DM. mTOR signalling in growth control and disease. Cell. 2012;149:274-93.

56. Lee SJ. Regulation of muscle mass by myostatin. Ann Rev Cell Dev Biol. 2004;20:61-86

57. Elliott B, Renshaw D, Getting S, Mackenzie R. The central role of myostatin in skeletal muscle and whole body mass homeostasis. Acta Physiol. 2012; 205:324-40.

58. Rodriguez J, Vernus B, Chelh I, Cassar-Malek I, Gabillard JC, Sassi AH, Seiliez I, Picard B, Bonnieu A. Myostatin and the skeletal muscle atrophy and hypertrophy signalling pathways. Cell Mol Life Sci. 2014;71:4361-71.

59. McPherron AC, Lawler AM, Lee SJ. Regulation of skeletal muscle mass in mice by a new TGF- $\beta$ superfamily member. Nature. 1997;387:83-90.

60. Zimmers TA, Davies MV, Koniaris LG, Haynes P, Esquela AF, Tomkinson KN, McPherron AC, Wolfman NM, Lee SJ. Induction of cachexia in mice by systemically administered myostatin. Science. 2002;296:1486-8.

61. Grobet L, Pirottin D, Farnir F, Poncelet D, Royo LJ, Brouwers B, Christians E, Desmecht D, Coignoul F, Kahn R, George M. Modulating skeletal muscle mass by postnatal, muscle-specific inactivation of the myostatin gene. Genesis. 2003;35(4):227-38.

62. Tsuchida K. Myostatin inhibition by a follistatin-derived peptide ameliorates the pathophysiology of muscular dystrophy model mice. Acta Myology. 2008;27:14-8.

63. Gonzalez-Cadavid NF, Taylor WE, Yarasheski K, Sinha-Hikim I, Ma K, Ezzat S, Shen R, Lalani R, Asa S, Mamita M, Nair G, Arver S, Bhasin S. Organization of the human myostatin gene and expression in healthy men and HIV-infected men with muscle wasting. Proc Natl Acad Sci USA. 1998; 95(25):14938-43.

64. Taylor WE, Bhasin S, Artaza J, Byhower F, Azam M, Willard DH Jr, Kull FC Jr, Gonzalez-Cadavid N. Myostatin inhibits cell proliferation and protein synthesis in C2C12 muscle cells. AmJ Physiol End Met. 2001; 280:E221-8.

65. Artaza JN, Bhasin S, Mallidis C, Taylor W, Ma K, Gonzalez-Cadavid NF. Endogenous expression and localization of myostatin and its relation to myosin heavy chain distribution in C2C12 skeletal muscle cells. J Cell Physiol. 2002;190:170-9.

66. Hill JJ, Davies MV, Pearson AA, Wang JH, Hewick RM, Wolfman NM, Qiu Y. The myostatin propeptide and the follistatin-related gene are inhibitory binding proteins of myostatin in normal serum. J Biol Chem. 2002;277:40735-41.

67. Jiang MS, Liang LF, Wang S, Ratovitski T, Holmstrom J, Barker C, Stotish R. Characterization and identification of the inhibitory domain of GDF-8 propeptide. Biochem Biophy Res Comm. 2004;315:525-31.

68. Attisano L, Wrana JL. Signal transduction by the TGF- $\beta$ superfamily. Science. 2002;296:1646-7.

69. Lee SJ, McPherron AC. Regulation of myostatin activity and muscle growth. Proc Natl Acad Sci USA. 2001;98:9306-11.

70. Bradley L, Yaworsky PJ, Walsh FS. Myostatin as a therapeutic target for musculoskeletal disease. Cell Mol Life Sci. 2008;65:2119-24.

71. Derynck R, Zhang Y, Feng XH. Smads: transcriptional activators of TGF-beta responses. Cell. 1998;95:737-40.

72. Joulia-Ekaza D, Cabello G. Myostatin regulation of muscle development: Molecular basis, natural mutations, physiopathological aspects. Exp Cell Res. 2006:312:2401-14.

73. Miyazawa K, Shinozaki M, Hara T, Furuya T, Miyazono K. Two major smad pathways in TGF- $\beta$ superfamily signalling. Genes Cell. 2002;7:1191-204

74. Yan XH, Chen YG. Smad7: Not only a regulator, but also a cross-talk mediator of TGF- $\beta$ signalling. Biochem J. 2011;434:1-10.

75. Zhu X, Topouzis S, Liang LF, Stotish RL. Myostatin signalling through Smad2, Smad3 and Smad4 is regulated by the inhibitory Smad7 by a negative feedback mechanism. Cytokine. 2004a;26:262-72.
76. Forbes D, Jackman M, Bishop A, Thomas M, Kambadur R, Sharma M Myostatin auto-regulates its expression by feedback loop through Smad7 dependent mechanism. J Cell Physiol. 2006;206:264-72.

77. Goodman CA, McNally RM, Hoffmann FM, Hornberger TA. Smad3 induces atrogin-1, inhibits mtor and protein synthesis, and promotes muscle atrophy in vivo. Mol End. 2013:27:1946-57.

78. Lokireddy S, McFarlane C, Ge XJ, Zhang HM, Sze SK, Sharma M, Kambadur R. Myostatin induces degradation of sarcomeric proteins through a smad3 signaling mechanism during skeletal muscle wasting. Mol End. 2011;25:1936-49.

79. Trendelenburg AU, Meyer A, Rohner D, Boyle J, Hatakeyama S, Glass DJ. Myostatin reduces Akt/TORC1/p70S6K signaling, inhibiting myoblast differentiation and myotube size. Am J Physiol Cell Physiol. 2009;296:C1258-70

80. Velloso CP. Regulation of muscle mass by growth hormone and IGF-1. $\mathrm{Br}$ J Pharmacol. 2008;154:557-68.

81. Beermann DH, DeVol D. Effects of somatotrophin, somatotrophin releasing factor and somatostatin on growth. In: Pearson AM, Dutson TR, editors. Growth Regulation in Farm Animals. Advances in Meat Research, vol. 7. London: Elsevier; 1991. p. 373-426.

82. Etherton TD, Bauman DE. Biology of somatotrophin in growth and lactation of domestic animals. Physiol Rev. 1998;78:745-61.

83. Salvatore D, Simonides WS, Dentice M, Zavacki AM, Larsen PR. Thyroid hormones and skeletal muscle: New insights and potential implications. Nat Rev End. 2014;10:206-14.

84. Alshehri B, D'Souza DG, Lee JY, Petratos S, Richardson SJ. Diversity of mechanisms influenced by transthyretin in neurobiology: Development, disease and endocrine disruption. J Neuroend. 2015;27:303-23.

85. Mendel CM, Weisiger RA, Jones AL, Cavalieri RR. Thyroid hormone binding proteins in plasma facilitate uniform distribution of thyroxine within tissues - a perfused rat liver study. Endocri. 1987;120:1742-9.

86. Schreiber G, Richardson SJ. The evolution of gene expression, structure and function of transthyretin. Comp Biochem Physiol B; Biochem Mol Biol. 1997:116:137-60.

87. Aleshire SL, Bradley CA, Richardson LD, Parl FF. Localization of human prealbumin in choroid plexus epithelium. J Histo Cytochem. 1983;31:608-12.

88. Dickson PW, Aldred AR, Menting JG, Marley PD, Sawyer WH, Schreiber G. Thyroxine transport in choroid plexus. J Biol Chem. 1987;262:13907-15.

89. Raz A, Goodman DS. The interaction of thyroxine with human plasma prealbumin and with the prealbumin-retinol-binding protein complex. J Biol Chem. 1969;244:3230-7.

90. Darras VM, Houbrechts AM, Van Herck SL. Intracellular thyroid hormone metabolism as a local regulator of nuclear thyroid hormone receptormediated impact on vertebrate development. Biochim Biophys Acta. 1849; 2015:130-41.

91. Hancock DL, Wagner JF, Anderson DB. Effects of estrogens and androgens on animal growth. In: Pearson AM, Dutson TR, editors. Growth Regulation in Farm Animals. Advances in Meat Research, vol. 7. Elsevier Applied Science: New York, NY; 1991. p. 255-97.

92. Spencer GSG. Hormonal systems regulating growth. A review. Livesto Prod Sci. 1985;12:31-46.

93. Florini JR. Hormonal-control of muscle growth. Mus Nerve. 1987;10:577-98.

94. Lee EJ, Choi J, Hyun JH, Cho KH, Hwang I, Lee HJ, Chang J, Choi I. Steroid effects on cell proliferation, differentiation and steroid receptor gene expressionin adult bovine satellite cells. Asian-Austra J Anim Sci. 2007;20:501-10.

95. Wheeler TL, Koohmaraie M. Prerigor and postrigor changes in tenderness of bovine longissimus muscle. J Anim Sci. 1994;72:1232-8.

96. Maltin CA, Delday MI, Hay SM, Innes GM, Williams PE. Effects of bovine pituitary growth hormone alone or in combination with the beta-agonist clenbuterol on muscle growth and composition in veal calves. Brit J Nutr. 1990;63:535-45.

97. Beermann DH, Butler WR, Hogue DE, Fishell VK, Dalrymple RH, Ricks A, Scanes CG. Cimaterol-induced muscle hypertrophy and altered endocrine status in lambs. J Anim Sci. 1987;65:1514-24.

98. Sainz RD, Kim YS, Dunshea FR, Campbell RG. Effects of ractopamine in pig muscles - histology, calpains and $\beta$-adrenergic receptors. Aust J Agric Res. 1993:44:1441-8.

99. Rehfeldt C, Schadereit R, Weikard R, Reichel K. Effect of the beta-adrenergic agonist clenbuterol on growth, carcass and skeletal muscle characteristics in broiler chickens. Br Poult Sci. 1997;38:368-75. 
100. Klont RE, Brocks L, Eikelenboom G. Muscle fibre type and meat quality. Meat Sci. 1998;49(1):S219-29.

101. Seideman SC, Crouse JD. The effects of sex condition, genotype and diet on bovine muscle fiber characteristics. Meat Sci. 1986;17:55-72

102. Jeremiah LE, Gibson LL, Aalhus JL, Dugan MER. Assessment of palatability attributes of the major beef muscles. Meat Sci. 2003;65:949-58.

103. Du M, Tong J, Zhao J, Underwood KR, Zhu M, Ford SP, Nathanielsz PW. Fetal programming of skeletal muscle development in ruminant animals. J Anim Sci. 2010a;88:E51-60.

104. Du M, Yan X, Tong JF, Zhao J, Zhu MJ. Maternal obesity, inflammation, and fetal skeletal muscle development. Biol Rep. 2010b;82:4-12

105. Feve B. Adipogenesis: cellular and molecular aspects. Best Prac Res; Clin Endo Met. 2005;19:483-99.

106. Beggs ML, Nagarajan R, Taylor-Jones JM, Nolen G, Macnicol M, Peterson CA. Alterations in the TGF- $\beta$ signaling pathway in myogenic progenitors with age. Aging Cell. 2004;3:353-61.

107. Bayol SA, Macharia R, Farrington SJ, Simbi BH, Stickland NC. Evidence that a maternal "junk food" diet during pregnancy and lactation can reduce muscle force in offspring. Eur J Nutr. 2009;48:62-5.

108. Petersen KF, Shulman Gl. Pathogenesis of skeletal muscle insulin resistance in type 2 diabetes mellitus. Am J Cardiol. 2002;90:11G-8G.

109. Aguiari P, Leo S, Zavan B, Vindigni V, Rimessi A, Bianchi K, Franzin C, Cortivo R, Rossato M, Vettor R, Abatangelo G, Pozzan T, Pinton P, Rizzutto R. High glucose induces adipogenic differentiation of muscle-derived stem cells. Proc Natl Acad Sci USA. 2008;105:1226-31.

110. Lahoute C, Sotiropoulos A, Favier M, Guillet-Deniau I, Charvet C, Ferry A, Butler-Browne G, Metzger D, Tuil D, Daegelen D. Premature aging in skeletal muscle lacking serum response factor. PLoS ONE. 2008;3:e3910.

111. Dodson MV, Fernyhough ME. Mature adipocytes: Are there still novel things that we can learn from them? Tis Cell. 2008:40:307-8.

112. Dodson MV, Jiang Z, Chen J, Hausman GJ, Guan LL, Novakofsi J, Thompson DP, Lorenzen CL, Fernyhough ME, Mir PS, Reecy JM. Allied industry approaches to alter intramuscular fat content and composition in beef animals. J Food Sci. 2010;75:R1-8.

113. Asakura A, Komaki M, Rudnicki M. Muscle satellite cells are multipotential stem cells that exhibit myogenic, osteogenic, adipogenic differentiation. Differentiation. 2001;68:245-53.

114. Fux C, Mitta B, Kramer BP, Fussenegger M. Dual regulated expression of C/EBP-alpha and BMP-2 enables differential differentiation of $\mathrm{C} 2 \mathrm{C} 12$ cells into adipocytes and osteoblasts. Nucleic Acid Res. 2004;32:e1.

115. Poulos S, Hausman G. A comparison of thiazolidinedione-induced adipogenesis and myogenesis in stromal-vascular cells from subcutaneous adipose tissue or semitendinosus muscle of postnatal pigs. J Anim Sci. 2006:84:1076-82.

116. Kook SH, Choi KC, Son YO, Lee KY, Hwang IH, Lee HJ, Chang JS, Choi IH, Lee JC. Satellite cells isolated from adult Hanwoo muscle can proliferate and differentiate into myoblasts and adipose-like cells. Mol Cell. 2006:22:239-45

117. Singh NK, Chae HS, Hwang $\mathrm{H}$, Yoo YM, Ahn CN, Lee SH, Lee HJ, Park HJ, Chung HY. Transdifferentiation of porcine satellite cells to adipoblasts with ciglitizone. J Anim Sci. 2007;85:1126-35.

118. Teboul L, Gaillard D, Staccini L, Inadera H, Amri EZ, Grimaldi PA. Thiazolidinediones and fatty acids convert myogenic cells into adipose-like cells. J Biol Chem. 1995;270:28183-7.

119. Hu E, Tontonoz P, Spiegelman BM. Transdifferentiation of myoblasts by the adipogenic transcription factors PPAR gamma and C/EBP alpha. Proc Natl Acad Sci USA. 1995;10:9856-60.

120. Tong J, Zhu MJ, Underwood KR, Hess BW, Ford SP, Du M. AMP-activated protein kinase and adipogenesis in sheep fetal skeletal muscle and 3T3-L1 cells. J Anim Sci. 2008;86:1296-305.

\section{Submit your next manuscript to BioMed Central and we will help you at every step:}

- We accept pre-submission inquiries

- Our selector tool helps you to find the most relevant journal

- We provide round the clock customer support

- Convenient online submission

- Thorough peer review

- Inclusion in PubMed and all major indexing services

- Maximum visibility for your research

Submit your manuscript at www.biomedcentral.com/submit

C Biomed Central 